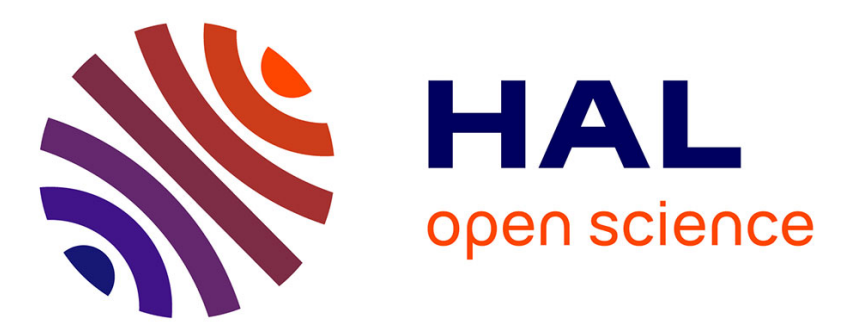

\title{
Simple method for detection of extremely diluted anti beta-casein antibodies from glass bead based receptors
}

\author{
A. Antoniou, G. Herlem, C. André, Y.-C. Guillaume, T. Gharbi
}

\section{To cite this version:}

A. Antoniou, G. Herlem, C. André, Y.-C. Guillaume, T. Gharbi. Simple method for detection of extremely diluted anti beta-casein antibodies from glass bead based receptors. Talanta, 2011, 84 (3), pp.632-637. 10.1016/j.talanta.2011.01.038 . hal-00595106

\section{HAL Id: hal-00595106 https://hal.science/hal-00595106}

Submitted on 5 May 2021

HAL is a multi-disciplinary open access archive for the deposit and dissemination of scientific research documents, whether they are published or not. The documents may come from teaching and research institutions in France or abroad, or from public or private research centers.
L'archive ouverte pluridisciplinaire HAL, est destinée au dépôt et à la diffusion de documents scientifiques de niveau recherche, publiés ou non, émanant des établissements d'enseignement et de recherche français ou étrangers, des laboratoires publics ou privés. 


\title{
Simple method for detection of extremely diluted anti beta-casein antibodies from glass bead based receptors
}

\author{
Alexandros Antoniou ${ }^{\mathrm{a}, *}$, Guillaume Herlem ${ }^{\mathrm{b}, \mathrm{d}}$, Claire Andréc, Yves Guillaumec ${ }^{\mathrm{c}}$, Tijani Gharbi ${ }^{\mathrm{b}, \mathrm{d}}$ \\ a Technological Institute of Larissa, Department of Medical Laboratories, TEI of Larissa, T.K. 41110 Larissa, Greece \\ b Institute Femto-ST/LOPMD CNRS UMR 6174, 16 Route de Gray, 25030 Besancon Cedex, France \\ ' Laboratoire de Chimie Analytique et Pharmaceutique EA 4267, Place Saint Jacques, 25030 Besancon Cedex, France \\ ${ }^{\mathrm{d}}$ CHU Jean Minjoz, Médecine Nucléaire, 3 bd Alexandre Fleming, 25030 Besancon Cedex, France
}

\begin{abstract}
The current work describes the elaboration of a simple, sensitive and reliable $\beta$-casein modified glass beads, for the detection and quantification of its specific antibody anti $\beta$-casein. This is an elementary receptor without electronic part, developed by grafting glass bead surface with the antigenic $\beta$ casein via 3-aminopropyltriethoxy silane and then glutaraldehyde as cross-linker. The whole is realized by a classical process, called in two steps and in mild conditions where chemical protocol is optimized for $\beta$-casein use. The detection and quantification of the specific reaction antibody-receptor is carried out by the technique of the second antibody labeled with horse radish peroxidase (HRP). Our receptor can detect the $\beta$-casein antibody present in the serum at dilutions up to a factor $10^{7}$ in strong ionic strength medium. The same antibody of the same serum and in the same conditions can be detected by ELISA test at dilutions up to a factor $10^{5}$. The whole test, after our receptor realization, takes about $5 \mathrm{~h}$.
\end{abstract}

\section{Introduction}

$\beta$-Casein is a protein [1] which is present in great quantities in bovine milk $[2,3]$ and it should be also noted that it differs very little from human $\beta$-casein [1], allowing a study comparable to that of the human one. It is a molecule which has antigenic properties $[4,5]$. It is also a powerful allergen [6] and more exactly a trophalergène [7].

The grafting of $\beta$-casein on a solid substrate can be useful for the development of an elementary receptor or immuno-assay of the corresponding anti $\beta$-casein antibody. Moreover, few studies are allocated to $\beta$-casein which is quite surprising and there is no description of a simple low cost and fast analytical test concerning anti $\beta$-casein antibody except ELISA test $[8,9]$. Receptor based sensor arrays require high cost equipment [10] (surface plasmon resonance measurement for instance) and receptor chip surface pre-treatment too.

Thus, it was an interesting challenge to develop a simple and fast quantitative receptor, using antigenic $\beta$-casein from cow's milk, for specific antibodies' titration and give rise to screening tests via enzyme immunoassay (EIA) measurements. In this purpose, we

\footnotetext{
* Corresponding author.

E-mail addresses: antalex@teilar.gr (A. Antoniou), guillaume.herlem@univ-fcomte.fr (G. Herlem).
}

grafted on a glass substrate ( $5 \mathrm{~mm}$ diameter glass bead) [11,12] the $\beta$-casein by a cross-linking reaction in two steps [13]. The crosslinking technique of a protein on glass is not recent but here it is suitable. It was found [14] indeed that the $\beta$-casein tertiary structure remains flexible and dynamic via cross-linking reactions. The protocol we used also allows mass-producing these functionalized glass beads.

Then, we optimized and tested this functional grafting on the glass beads in 96-well EIA plate thanks to the specific reaction of this receptor formed with its corresponding antibody anti $\beta$-casein. The quantification of this specific reaction is carried out by the technique of the second labeled antibody. Here the second antibody is labeled with peroxidase (HRP). Finally we compared the sensitivity of our elementary receptor with that of ELISA test versus the same antibody.

\section{Materials and methods}

\subsection{Reagents}

Glass beads ( $5 \mathrm{~mm}$ diameter) were purchased from VWR International, France. Glutaraldehyde of spectroscopic grade (25\% in aqueous solution), substrate peroxidase Fast OPD, EIA plate Maxisorp 96 wells, phosphate buffered solutions at $\mathrm{pH} 7.4 \times 10^{-2} \mathrm{M}$ (PBS), $\gamma$-aminopropyltriethoxysilane 99\% (3-APTES) and the bovine serum albumin (BSA) powder (minimum 98\%) were purchased 
1)

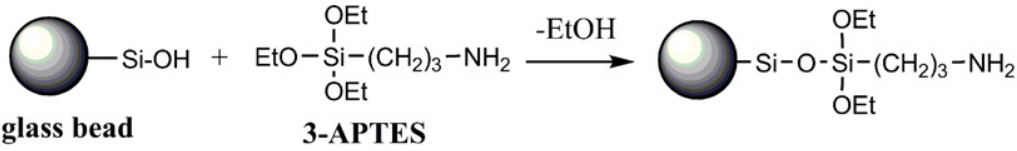

2)

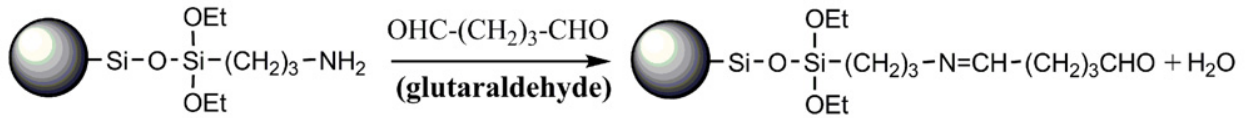

3)

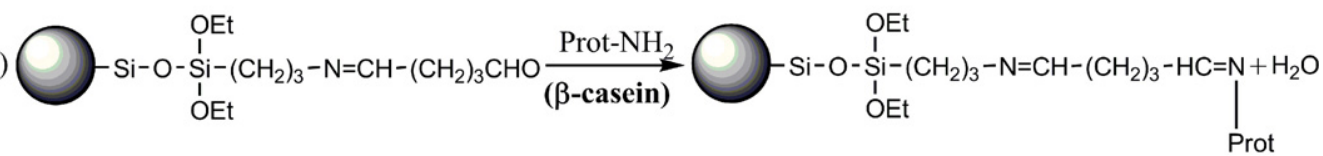

4)

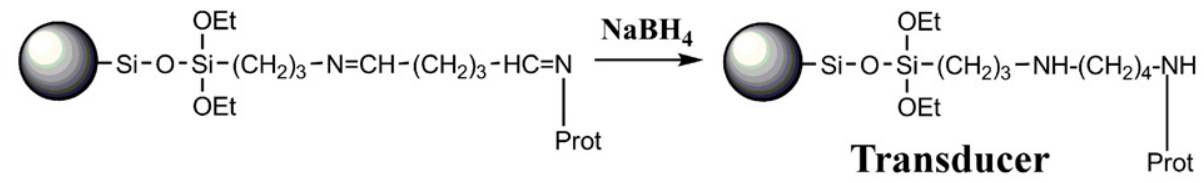

Fig. 1. The different steps of $\beta$-casein (Prot- $\mathrm{NH}_{2}$ ) covalent bonding on glass.

from Sigma-Aldrich, France. Polyclonal and monoclonal IgG antibodies and anti $\beta$-lactoglobulin antibody were produced in the laboratory (INRA, Poligny, France). The second antibody, horse radish peroxidase (HRP) conjugate, was purchased from P.A.R.I.S, France. Ultra pure water (Milli-Q, Millipore) was used when needed.

\subsection{General procedure of $\beta$-casein grafting on glass beads}

Glass beads were cleaned first by various solvents [15] to eliminate the stains and others surface contaminations. Thereafter a heat treatment was applied to eliminate water on bead surfaces [16] in order to perform only the silanization in anhydrous condition of the silica surface groups rather than with adsorbed water [17]. Then, immobilization reactions of biological components were carried out [18], until obtaining the receptor as shown in Fig. 1. This process is detailed in the following section.

\subsection{Treatment of glass before its silanization}

Glass beads were initially cleaned by two washings with acetone in order to eliminate grease from glass surface and facilitate the treatment with the following reagents:

- Aqueous molar solution of $\mathrm{HCl}$ for $20 \mathrm{~min}$, to remove basic stains.

- Aqueous molar solution of $\mathrm{NaOH}$ for $30 \mathrm{~min}$, to remove acid stains.

The glass surface was attacked by $\mathrm{NaOH}$ with formation of silicates as indicated below:

$\mathrm{SiO}_{2}+2 \mathrm{NaOH} \rightarrow \mathrm{Na}_{2} \mathrm{SiO}_{3}+\mathrm{H}_{2} \mathrm{O}$

Then, we carried out some washing with ultra pure water to remove excess of $\mathrm{NaOH}$ and obtain clean glass surface.

Glass beads were then thermically treated at $400^{\circ} \mathrm{C}$ for $4 \mathrm{~h}$ to remove the various layers of water adsorbed [16] on their surface. Actually, silanization in an anhydrous medium avoids side reactions with water. We can notice that glass bead whatever its nature, roughly contains on its surface 5.5 silanols nm-2 [19] and glass treated at $400{ }^{\circ} \mathrm{C}$ contains about 2.5 silanols $\mathrm{nm}^{-2}$ [20].

\subsection{Grafting of $\beta$-casein on glass balls}

Silanization was carried out when the glass beads were immersed in an anhydrous ethanol solution containing 0.6 wt.\% of 3-APTES [21] for $16 \mathrm{~h}$ in a dry atmosphere in a drying oven at $37^{\circ} \mathrm{C}$. We noted that eight glass beads are immersed in $1 \mathrm{~mL}$ of this solution. This step corresponds to the reaction 1 in Fig. 1 . Then, the glass beads were rinsed twice with anhydrous ethanol and four additional times with water for 5 min per washing to eliminate excess of 3-APTES which did not react with the glass beads. During these washings, the beads were carefully shaken so that they rub on to each other in order to eliminate the unreacted and adsorbed 3-APTES molecules. Some researchers suggest a cleaning of the silanized glass by rubbing it with a paper [22].

The resulting silanized glass beads were immersed in an aqueous glutaraldehyde (the crosslinker) solution at $1 \%$ for $90 \mathrm{~min}$. The reaction between the silanized balls and the aldehyde function of glutaraldehyde leads to the formation of the corresponding imine. This step corresponds to the reaction 2 in Fig. 1. Thereafter we carried out four successive washings of $5 \mathrm{~min}$ each one with ultra pure water to eliminate excess of glutaraldehyde which did not have reacted with silanized balls.

Thereafter we carried out $\beta$-casein grafting. The balls were immersed in a solution of PBS charged with $\beta$-casein at $10^{-2} \mathrm{mg} \mathrm{mL}^{-1}$ during $2 \mathrm{~h}$. We use $1 \mathrm{~mL}$ of this solution for the grafting of $\beta$-casein on 8 balls. This step is noted 3 in Fig. 1 and yields imine formation. Thereafter we carried out four successive washings of 5 min each one with ultra pure water to eliminate excess of $\beta$-casein.

For chemical instability reason [23], these imines have to be reduced [24] to stabilize the cross-linking. Note however that the imines formed with proteins are stables [24]. But in our case we have a stable imine formed with $\beta$-casein and an unstable one formed with the amino group of the 3-APTES grafted on the glass beads. Thus we must reduce theses imines to obtain the final and stable form of the receptor. The reduction step is 
carried out by placing the modified glass beads in an aqueous solution charged with $\mathrm{NaBH}_{4} 2 \mathrm{mg} \mathrm{mL}^{-1}$ for 75 min [18] followed by four washings with water for 5 min per washing (reaction 4 in Fig. 1).

At this stage the receptor we propose is ready for use.

\subsection{Checking of the functional fixing of $\beta$-casein and} quantification of receptor-antibody reaction

The reaction between our receptor and the anti $\beta$-casein antibody is carried out to check the functional grafting of the $\beta$-casein immobilized on the surface bead. This reaction is visualized by the action of a second antibody [25] anti-(anti $\beta$-casein) marked with the horseradish peroxidase (HRP). In the case of a positive reaction, the HRP of the second antibody colors the medium in presence of its substrate. This coloring is used to quantify ( $\beta$-casein)-(anti $\beta$-casein) reaction.

\subsection{Protocol and solutions for antigen antibody reaction}

Our receptors (functionalized glass bead with $\beta$-casein) are placed in the 96-well plate of test ELISA. Thereafter we add in the wells $200 \mu \mathrm{L}$ of different dilution from a rabbit serum containing antibody anti $\beta$-casein. We use dilutions from $10^{4}$ to $10^{7}$ times of this serum. The serum is diluted in a solution made of PBS charged with BSA at $0.5 \mathrm{~g} \mathrm{~L}^{-1}$, teween $200.05 \%$ and $\mathrm{NaCl} 0.5 \mathrm{M}$. Then the EIA plate is placed for $2 \mathrm{~h}$ in a drying oven at $37^{\circ} \mathrm{C}$.

After $2 \mathrm{~h}$, the antibodies solutions were removed from the wells containing the functionalized beads also called receptors. Four washings of $6 \mathrm{~min}$ each were carried out with washing solution. The washing solution consisted of the PBS charged with, teween 20 $0.05 \%$ and $\mathrm{NaCl} 0.5 \mathrm{M}$.

Then, $200 \mu \mathrm{L}$ of the second antibody solution (anti-anti- $\beta$ casein) labeled with HRP diluted 4000 times as indicated by the supplier, were added in the wells containing the receptors with fixing anti $\beta$-casein antibody (polyclonal antibody). The second antibody was diluted in the same solution as the previously first antibody anti $\beta$-casein.

The plate was put in the drying oven at $37^{\circ} \mathrm{C}$ for $90 \mathrm{~min}$. Then this solution was removed. Four washings of 6 min each were carried out with washing solution as described previously after reaction to the first antibody.

\subsection{Visualization and quantification of $\beta$-casein reaction immobilized on glass beads and its corresponding antibody}

In order to quantify this specific reaction, the receptors with the two fixed antibodies are transferred in proper plate wells EIA. Then $150 \mu \mathrm{L}$ of a substrate solution of enzyme peroxidase were added into the wells. This solution was prepared by dissolution of one pastille of substrate peroxidase Fast OPD in $20 \mathrm{~mL}$ of distillated water. After $5 \mathrm{~min}, 75 \mu \mathrm{L}$ of $\mathrm{HCl} 1 \mathrm{M}$ were added to stop the reaction of peroxidase with its substrate which colors the medium during this reaction.

The beads are left five additional minutes in the wells in order to promote the diffusion in the solution of the reaction products formed on the bead surface. Then the beads are removed from the wells to measure the absorbance of the color solutions at $490 \mathrm{~nm}$. This absorbance corresponds to the detection signal of the antigen antibody reaction we want to quantify.

\subsection{Surface characterization}

Surface topography was imaged with an atomic force microscope (AFM) using a MultiMode AFM scanner controlled by the PicoSPM system (Agilent, formerly Molecular Imaging, USA) in the

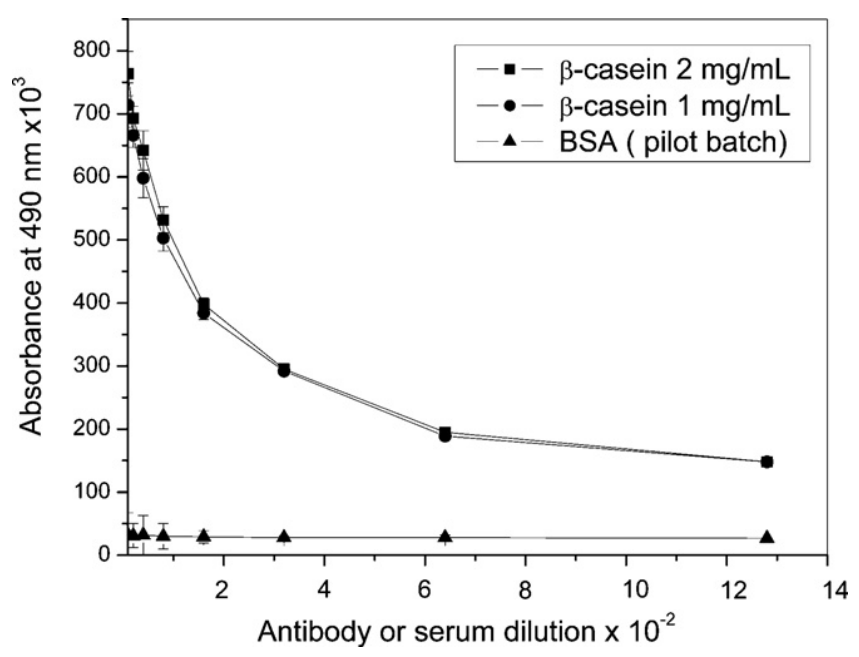

Fig. 2. Absorbance at $490 \mathrm{~nm}$ versus antibody (serum) dilution, by using the concentrations indicated on the graph for the coupling of $\beta$-casein on the glass. This is the case, when using "high concentrations" of $\beta$-casein for its coupling on glass. This experiment was performed with polyclonal antibody.

tapping mode with an aluminum coated silicon tip (PointProbe, Nanosensors).

\section{Results and discussion}

\subsection{Optimization of the glass bead based immune assay}

At first, in order to obtain the higher avidity of our receptor, we used high concentrations of $\beta$-casein in PBS for its grafting on glass. Thus we prepared two batches of $\beta$-casein at two different concentrations, 1 and $2 \mathrm{mg} \mathrm{mL}^{-1}$, to immobilize this protein on glass, as indicated elsewhere [11].

It should be noted that we prepared, in the same way, one pilot batch by fixing bovine serum albumin (BSA) on glass beads like previously with $\beta$-casein. Pilot batch was used for obtaining background noise and to prove the specificity of the reaction of receptor with its specific antibody anti $\beta$-casein. By application of the protocol exposed in paragraph protocol and solutions for antigen antibody reaction to all these batches, we obtained the results shown in Fig. 2. These results were not very satisfactory because a weak absorbance for the detection of small antibody quantities was observed.

Consequently, we reproduced the same $\beta$-casein grafting experiments as previously but with lower concentrations of protein, at $10^{-2} \mathrm{mg} \mathrm{mL}^{-1}$. The results obtained are shown in Fig. 3. The values of the absorbance obtained are more important than those obtained with receptors elaborated with high concentrations of $\beta$-casein of 1 and $2 \mathrm{mg} \mathrm{mL}^{-1}$ as evocated previously.

In order to determine the optimal concentration of $\beta$-casein to be used for its grafting on glass for the realization of the receptor, we prepared various batches of glass beads (always in the same way) varying only the $\beta$-casein concentration (reaction 3 in Fig. 1 ) on the glass beads. Consequently, we prepared five batches of 8 glass beads of each one with various $\beta$-casein concentrations. The resulting modified glass beads were tested on the same way as before with the technique of the second marked antibody. The results are shown in Fig. 4. We can notice that the maximum of absorbance (see Fig. 4) corresponds to the batch of the receptors prepared with a concentration in $\beta$-casein of $10^{-2} \mathrm{mg} \mathrm{mL}^{-1}$.

Thus we can conclude that $1 \mathrm{~mL}$ at this concentration contains the right quantity of $\beta$-casein to functionalize the 8 glass beads of the batch. 


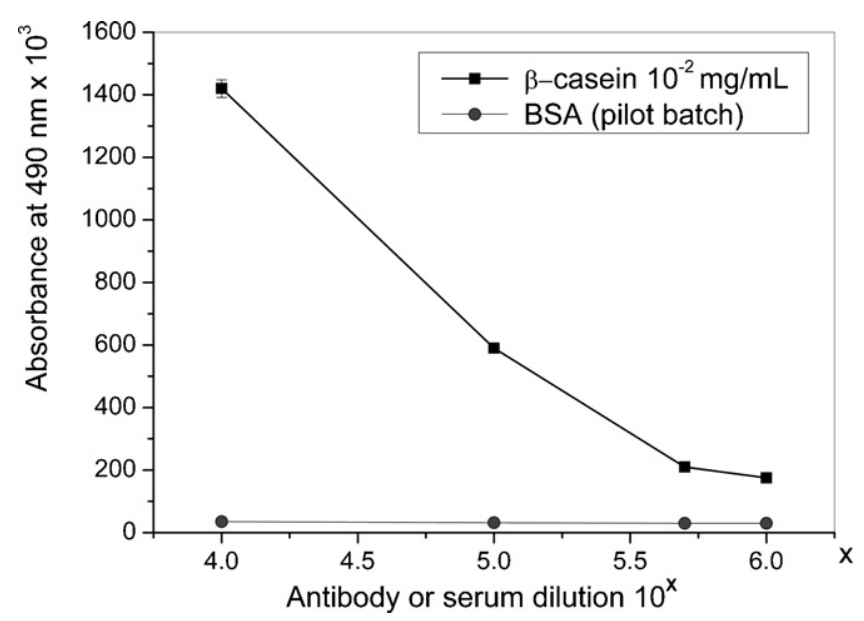

Fig. 3. Absorbance at $490 \mathrm{~nm}$ versus antibody (serum) dilution, by using the concentrations indicated on the graph for the coupling of $\beta$-casein on the glass. This is the case, when using "low concentrations" of $\beta$-casein for its coupling on glass. This experiment was performed with polyclonal antibody.

\subsection{Specific reaction of our receptor due to the casein fixed on the glass beads by a covalent way}

The effective $\beta$-casein grafting on the glass beads was brought out by changing the cross-linking sequence from the straightforward development process of the receptor that can be written:

$\mathrm{B}+\mathrm{A}+\mathrm{G}+\mathrm{P} \rightarrow(\mathrm{B}-\mathrm{A}-\mathrm{G}-\mathrm{P})$

where $B$ is the bead, $A$ is 3-APTES, $G$ is glutaraldehyde, $P$ is the $\beta$-casein and $(B-A-G-P)$ is the modified glass bead once reduced by $\mathrm{NaBH}_{4}$ to obtain the final and stable form of the receptor. The lack of one of these chemical steps causes the absence of $\beta$-casein grafting on the glass beads and consequently no absorbance at the end of the ELISA test. In this purpose, we prepared and tested as previously the following batches:

- Batch, normal procedure of $\beta$-casein grafting, noted $B-A-G-P$.

- Batch, normal procedure but without participation of $A$, noted B-G-P.

- Batch, normal procedure but without participation of $G$, noted B-A-P.

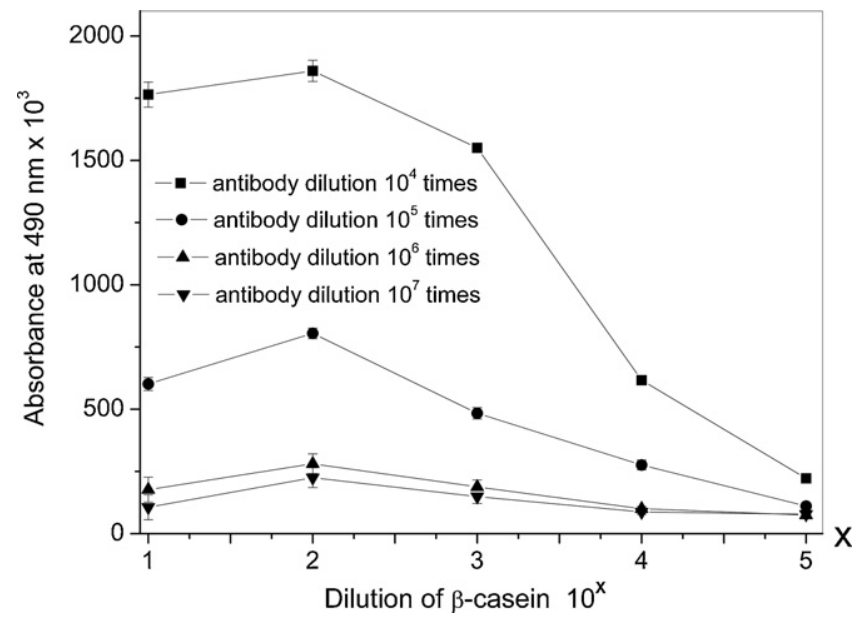

Fig. 4. Absorbance at $490 \mathrm{~nm}$ versus $\beta$-casein dilution used for the coupling of this protein on the glass balls. Initial concentration of $\beta$-casein: $1 \mathrm{mg} \mathrm{mL}^{-1}$. Dilutions of antibodies (serum) are indicated on the graph. The absorbance corresponds to the average of the absorbance of two balls (receptors) by dilution of antibodies.

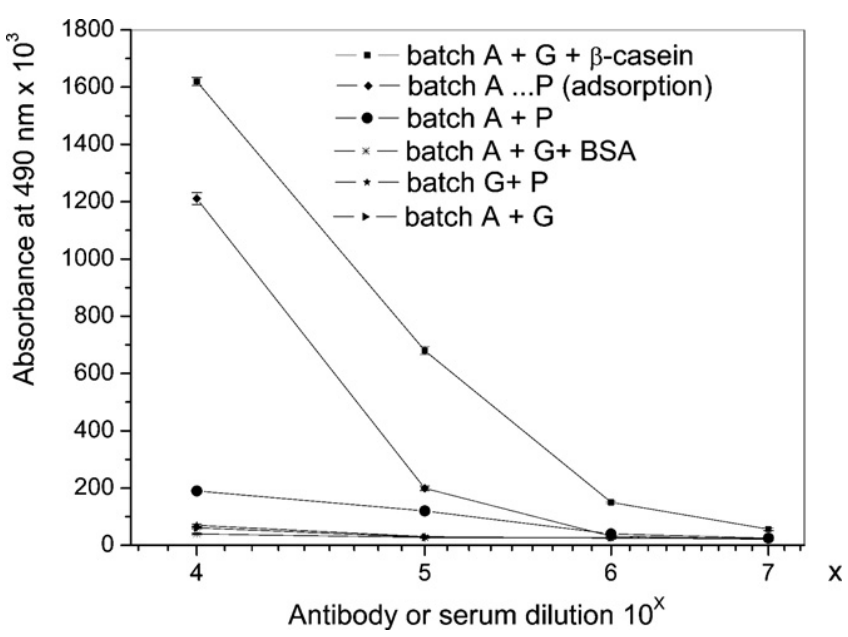

Fig. 5. Absorbance at $490 \mathrm{~nm}$ as a function of antibody (serum) dilution, when we use the various batches with or without the components of the coupling as indicated on the graph.

- Batch, normal procedure but without participation of $\mathrm{P}$, noted B-A-G.

- Batch, adsorption of $\beta$-casein on silanized beads, noted B-A . .P.

- Batch, normal procedure of pilot BSA grafting, noted B-A-G-BSA.

The results we obtained are displayed in Fig. 5. We can see that:

- Only the batch B-A-G-P has a very strong absorbance. This is normal since this batch has undergone all the reactions of coupling with the $\beta$-casein grafting,

- the batch B-A ..P. has a strong absorbance but only for high antibody concentrations. This absorbance range remains always lower than that of batch B-A-G-P, corresponding to normal procedure. It should also be noted that adsorption of protein $\beta$ casein on silanized glass beads is very strong compared to the non-silanized glass beads. This fact explains the relatively strong absorbance of this batch. We checked this with other experiments that are not mentioned here,

- all the other batches that have not undergone all the coupling reactions show very weak absorbance, and therefore lead to the conclusion that there is a very weak grafting or adsorption of $\beta$-casein on these beads,

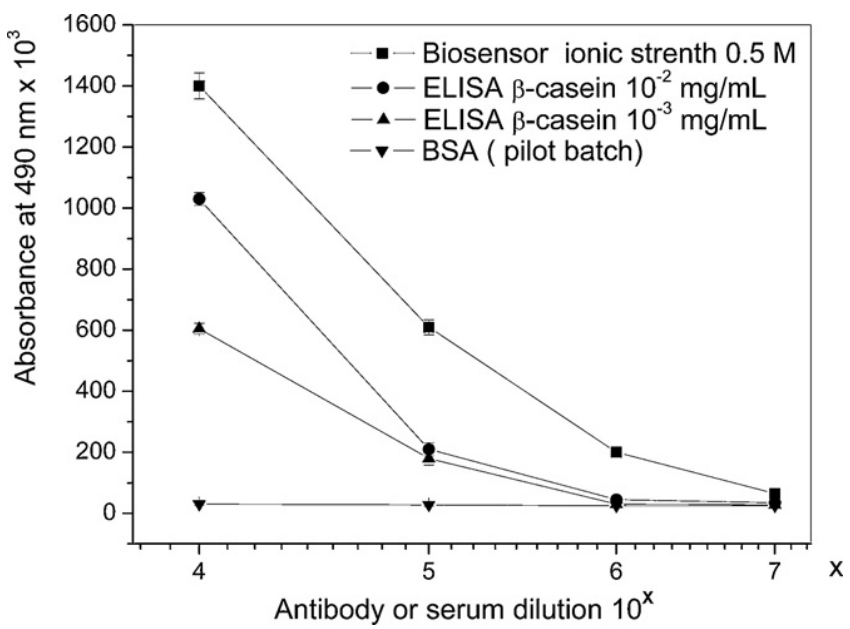

Fig. 6. Absorbance at $490 \mathrm{~nm}$ as a function of antibody (serum) dilution. ELISA test and receptor comparison. 

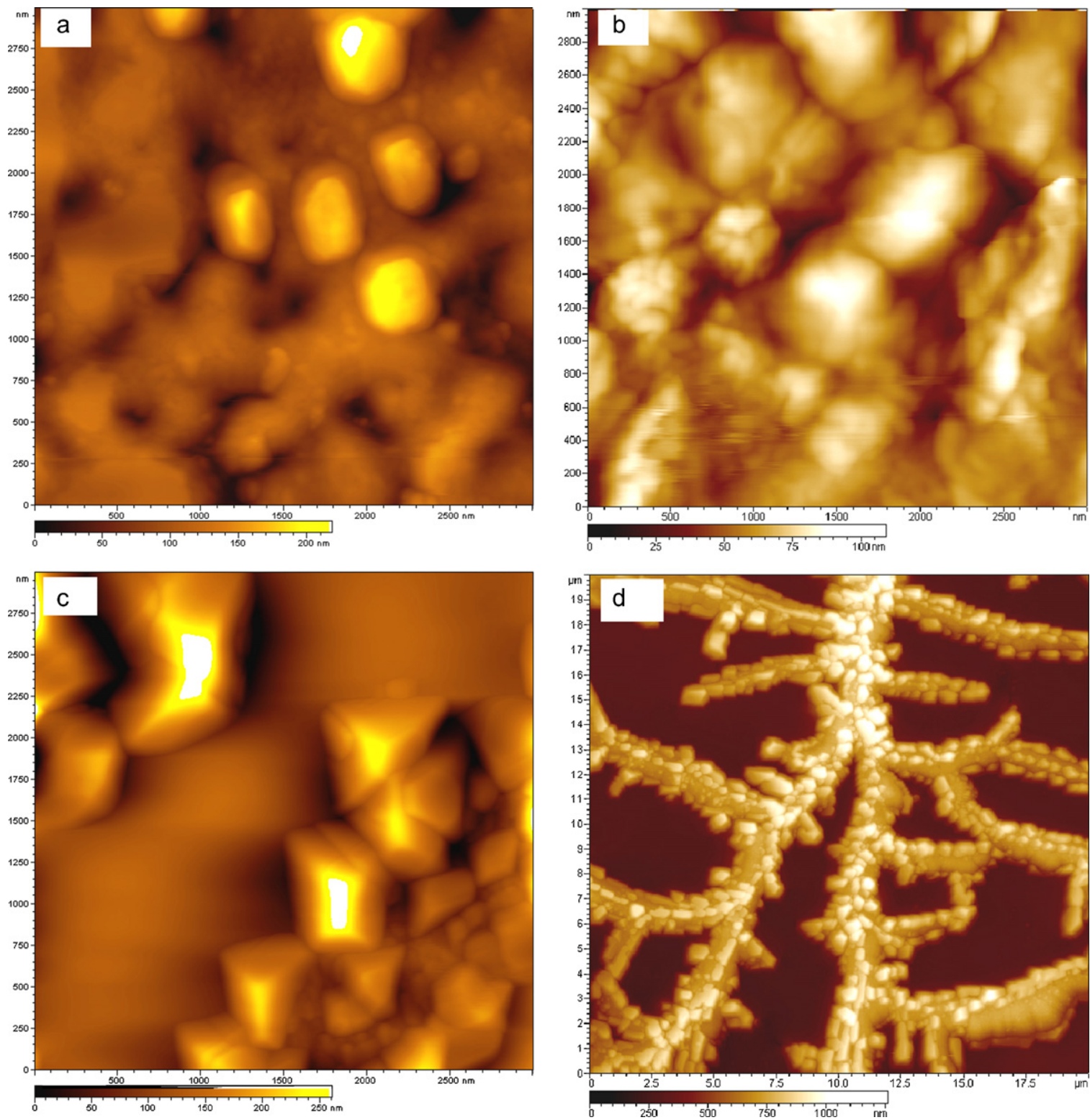

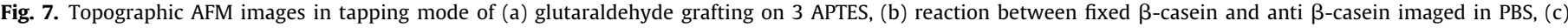
crystallization of the $\beta$-casein-anti $\beta$-casein complex at air 15 days after the reaction occurs and (d) 6 months after.

- the pilot batch, using BSA instead $\beta$-casein, does not present absorption either, which proves the specificity of the $\beta$-casein reaction with its antibody.

All these results prove that there is a real, well-ordered and effective coupling between the various described components for receptor realization. The lack of reaction with the pilot batch proves also the specificity of our receptor. Notice that when we use a monoclonal antibody anti $\beta$-casein to carry out the same experiments, we obtain completely similar results. When we use a polyclonal antibody anti $\beta$-lactoglobulin to carry out the same experiments, we obtain a very weak absorbance. This is also the favor of the specificity of our receptor.

\subsection{Comparison of our receptor with the test ELISA}

In order to compare the sensitivity of our antibody anti $\beta$-casein based receptor with ELISA test, we performed the adsorption of $\beta$-casein in ELISA plate wells by using two different concentrations: $10^{-2}$ and $10^{-3} \mathrm{mg} \mathrm{mL}^{-1}$ of $\beta$-casein in PBS. Then, we tested one batch of receptors and one ELISA plate well with adsorbing $\beta$-casein. We carried out the comparison test by using for our receptor the usual medium of antibodies dilution and washing solutions at the usual ionic strength of $0.5 \mathrm{M}$. For ELISA plate experiments, we used very low concentration, and then very favorable antibody detection condition of $0.1 \mathrm{M}$ ionic strength. From the results displayed in Fig. 6, we can underline that our receptor have much higher sensitivity to antibodies detection than that of ELISA test. Especially, the superiority lies in the detection of weak antibody concentrations at high ionic strength. We note that if we use ionic force of $0.5 \mathrm{M}$ with test ELISA, we detect only very high antibody concentrations. More exactly, concentrations are about 200 times greater than those obtained with our receptor are detected and that still depends on the concentration we used for adsorption. The effect of concentration used for $\beta$-casein adsorption on the ELISA plate is shown in Fig. 6. If we use for $\beta$-casein adsorption a con- 
centration of $10^{-3} \mathrm{mg} \mathrm{mL}^{-1}$ and ionic strength $0.5 \mathrm{M}$, detection is almost destroyed.

We mentioned that it is possible to produce our receptor massively. Despite the fact that some slight differences could happen from one batch to another one due to experimental fluctuations, we have had very weak fluctuation and the antibody detection is very reproducible.

\subsection{Surface characterization}

AFM topographic images Fig. 7 show surface modifications related to glass functionalization and $\beta$-casein reaction with its antigen. Fig. 7a displays in situ characterization in PBS of the glass surface after glutaraldehyde grafting (reaction 2, Fig. 1). There is a drastic change once the reaction between $\beta$-casein and anti $\beta$ casein is performed as shown Fig. 7b (reaction 4, Fig. 1 ) where a complete surface coverage occurred. Despite abundant washing and after a fortnight at air, the chemical modification is persistent. There is stabilization of the cross-linked $\beta$-casein which crystallizes Fig. 7c and keeps a fractal appearance even after 6 months Fig. 7d.

\section{Conclusion}

We can say, from the results we obtained during the quantification of the reaction between antibody anti $\beta$-casein and antigen fixed on the glass beads (receptor), that the grafting is functional. There is indeed antibody fixing in a way proportional to its concentration in all the experiments. The receptor can detect very low antibody concentrations compared to ELISA test. More exactly, we estimated that ELISA test detection was 100-200 times weaker under the same conditions of ionic strength. It is known that the strong ionic strength is a big factor when we want to eliminate the interferences in the antibody-antigen reactions. It is clear that the strong ionic strength can tear off adsorbed $\beta$-casein with the antibodies of the ELISA plate. Consequently there is a strong decrease of antibody detection with this method. On the contrary, with our receptor, $\beta$-casein is linking in a covalent way on the glass. Consequently the complex antibody antigen cannot be torn off by salts explaining why we have strong detection in this case.

The experimental procedures described above allow a mass production of the receptors. We do not have to try to re-use the receptor because of its low cost. Moreover, the receptors we described here have a persistent and reliable activity over one year even when kept at dry state in a sealed box at room temperature. Thus the time of a test, since we can produce receptor in mass is reduced to $5 \mathrm{~h}$ compared to the ELISA test which at least requires $8 \mathrm{~h}$. The receptor is very handy considering its size and can be also used for the same tests in haemolysis tubs instead of ELISA plate.

\section{Acknowledgment}

The authors gratefully acknowledge the INRA of Poligny, France (Dr. D. Dupont) for supplying anti $\beta$-casein and others materials.

\section{References}

[1] N. Farriol-Mathis, J.S. Garavelli, B. Boeckmann, S. Duvaud, E. Gasteiger, A. Gateau, A.L. Veuthey, A. Bairoch, Proteomics 4 (2004) 1537.

[2] C. Alain, G. Linden, L. Miclo, Biochimie Alimentaire, Dunod, Paris, 2003, ISBN: 2-10-003827-3.

[3] J.A. O'Mahony, K.E. Smith, J.A. Lucey, Purification of beta casein from milk, Patent WO/2007/055932, 2007.

[4] J. Charlemagne, Le Système Immunitaire, Hermann, Paris, 1989, ISBN: 2-70566046-8.

[5] H. Bernard, L. Negroni, J.M. Chatel, G. Clement, K. Adel-Patient, G. Peltre, C. Creminon, J.M. Wal, Mol. Immunol. 37 (2000) 161.

[6] D. Moneret-Vautrin, Food Allergens, 4th ed., Flammarion, Paris, 2004.

[7] S. La Vieille, C. Dubuisson, A. Martin, Rev. Fr. Lab. 348 (2002) 39.

[8] L. Monetini, M.G. Cavallo, L. Stefanini, F. Ferrazzoli, C. Bizzarri, G. Marietti, V. Curro, M. Cervoni, P. Pozzilli, Diabetes Metab. Res. Rev. 1 (17) (2000) 51.

[9] I.P. Hurley, R.C. Coleman, H.E. Ireland, J.H.H. Williams, Int. Dairy J. 16 (7) (2006) 805.

[10] H. Minh Hiep, T. Endo, K. Kerman, M. Chikae, D.K. Kim, S. Yamamura, Y. Takamura, E. Tamiya, Sci. Technol. Adv. Mater. 8 (2007) 331.

[11] Y. Hamagutsi, K. Kato, H. Fukui, I. Shirikawa, E. Isikawa, K. Koboyashi, N. Katunuma, J. Biochem. 80 (1976) 895.

[12] P.J. Robinson, P. Dunnill, M.D. Lilly, Biochim. Biophys. Acta 242 (1971) 659

[13] S. Avrameas, T. Ternynck, Immunochemistry 8 (1971) 1175.

[14] Y.D. Livney, A.L. Schwan, D.G. Dalgleish, J. Dairy Sci. 87 (2004) 3638

[15] J.J. Cras, A.C. Rowe-Taitt, D.A. Nivens, F.S. Ligler, Recept. Bioelect. 14 (1999) 683.

[16] R.P.W. Scott, S. Traiman, J. Chromatogr. 196 (1980) 193.

[17] E.T. Vandenberg, L. Bertilsson, B. Liedberg, K. Uvdal, R. Erlandsson, H. Elwing, I. Lundström, J. Newspaper Colloid Interf. Sci. 147 (1991) 103.

[18] G. Hermanson, Bioconjugate Techniques, Academic Close, San Diego, CA, 1996

[19] L.T. Zhuravlev, Langmuir 3 (1987) 316.

[20] L.T. Zhuravlev, Colloids Surf. A: Physicochem. Eng. Aspects 74 (1993) 71

[21] E.P. Plueddemann, Silane Coupling Agents, Plenum Near, New York, 1982.

[22] A. Simon, PhD Thesis, Bordeaux I (France), 2002.

[23] J. Clayden, N. Geeves, S. Warren, P. Wothers, Oxford University Press, 2000, ISBN 0-198-50346-6.

[24] K.P.C. Vollhardt, N.E. Schore, Organic Chemistry, W.H. Freeman and Company, 2006, ISBN: 978-0-7167-7235-4.

[25] P. Kamoun, Appareils et méthodes en Biochimie et biologie moléculaire, Flammarion Paris, 1997, ISBN: 2-257-15545-9. 